\title{
PENGARUH EXCESS CASH DAN INSUFFICIENT CASH TERHADAP KINERJA PERUSAHAAN DAN REAKSI PASAR (STUDI PADA PERUSAHAAN YANG TERDAFTAR DI BEI TAHUN 2010-2013)
}

\begin{abstract}
The objects of this research were nonfinancial companies registered on Indonesian Stock Exchange with samples of 79 companies on 2010-2013 (including time lag). Data was analyzed usingPooled Least Square regression with Eviews software as the tool. Using 5\% significancy level, this research implied that (1) excess cash had positive significant influence on firm performance, (2) insufficient cash had positive but no significant influence on firm performance, (3) excess cash had negative but no significant influence on market reaction, and (4) insufficient cash had negative significant influence on market reaction. These results implied that the market responded to insufficient cash more than excess cash in the companies and firm performance would be increasing because of excess cash due to the decrease of external financing cost.
\end{abstract}

\footnotetext{
ABSTRAK: Penelitian ini dilakukan pada perusahaan yang terdaftar di Bursa Efek Indonesia dengan mengambil sampel sebanyak 79 perusahaan selama tiga periode (termasuk time lag) dengan data tahun 2010-2013 yang terdiri dari semua industri nonkeuangan. Pengolahan data dilakukan dengan menggunakan teknik analisis regresi panel berganda Pooled Least Square dengan bantuan software Eviews. Hasil penelitian dengan menggunakan taraf signifikansi 5\% satu arah menunjukkan bahwa (1) excess cash berpengaruh positif signifikan terhadap kinerja, (2) insufficient cash berpengaruh positif tidak signifikan terhadap kinerja, (3) excess cash berpengaruh negatif tidak signifikan terhadap reaksi pasar, dan (4) insufficient cash berpengaruh negatif signifikan terhadap reaksi pasar. Kesimpulan yang dapat diambil bahwa pasar lebih merespon kondisi kekurangan kas dibanding kelebihan kas, dan bahwa kelebihan kas dapat membuat kinerja meningkat dengan penurunan external financing cost.
}

Merri Dwi Nurrani', Evita Puspitasari ${ }^{2}$, Rolland E. Fanggidae ${ }^{3}$ 1,2,3 Jurusan Akuntansi, Universitas Padjadajran Bandung, Jawa Barat E-mail: merri_dn@yahoo.com

Keywords: Cash, Excess Cash, Insufficient Cash, Firm Performance, Market Reaction.

Kata Kunci: Cash, Excess Cash, Insufficient Cash, Kinerja Perusahaan, Reaksi Pasar. 


\section{PENDAHULUAN}

\subsection{Latar Belakang}

Tidak dapat dipungkiri lagi bahwa kas merupakan aset yang sangat penting bagi perusahaan. Di samping karakteristiknya sebagai aset paling likuid, kas memegang peranan penting agar perusahaan dapat menjalankan transaksi-transaksinya menggunakan uang sebagai unit monetary exchange. Perusahaan yang memiliki banyak kas tentu bisa dikatakan sebagai perusahaan yang likuid, artinya perusahaan tersebut dapat menjamin transaksi-transaksi yang bersifat jangka pendek. Namun memegang terlalu banyak kas dalam perusahaan juga memiliki dampak terhadap produktivitas perusahaan. Kas merupakan aset yang tidak produktif, sehingga jika perusahaan menahan sejumlah kas yang besar dalam posisi keuangannya, tentu akan terjadi idle cash dan perusahaan kehilangan kesempatan untuk memperoleh keuntungan lain jika kas tersebut digunakan untuk investasi, misalnya.

Isu manajemen kas selalu menjadi bahasan yang tak kunjung usai. Setiap perusahaan memiliki manajemen kasnya masing-masing. Menurut Harmono (2011:197), karena sifatnya yang tidak produktif, kas harus dimiliki seminimal mungkin oleh perusahaan. Namun, di sisi lain perusahaan membutuhkan banyak kas untuk kegiatan operasional sehingga perlu dicari posisi kas optimal.

Banyak perusahaan yang memegang jumlah kas lebih banyak dari jumlah kas optimal mereka. Fenomena yang terjadi di Amerika (berdasarkan penelitian Bates, et al., 2009) menggambarkan terdapat peningkatan average cash ratio secara drastis pada perusahaan-perusahaan di United States dari tahun 1980 hingga 2006. Cash ratio merupakan salah satu rasio yang digunakan unuk mengukur kecukupan kas. Berbicara mengenai kas, tentu saja semakin banyak memiliki kas maka likuiditas perusahaan semakin baik dan perusahaan dapat berjaga-jaga untuk transaksitransaksi yang akan dilakukan kemudian hari. Menurut Keynes (1935), terdapat tiga motif perusahaan dalam memegang kas, yakni motif transaksi (untuk melakukan transaksi bisnis perusahaan), motif pencegahan/precautionary motive (untuk berjaga-jaga jika ada kebutuhan yang tiba-tiba), dan motif spekulasi (untuk memperoleh suatu keuntungan dari situasisituasi yang diharapkan dapat menguntungkan, misalnya investasi).

Di luar negeri telah banyak penelitianpenelitian mengenai jumlah kas perusahaan dan pengaruhnya terhadap beberapa aspek. Penelitian ini didasari oleh kondisi perusahaanperusahaan yang memiliki jumlah kas yang sangat besar dalam laporan keuangan perusahaan, melebihi tingkat optimalnya. Di Indonesia masih sedikit penelitian mengenai excess cash ini. Dilihat dari kondisi perusahaan-perusahaan di Indonesia, banyak juga perusahaan yang memiliki saldo kas yang besar dalam laporan keuangannya dan jumlahnya fluktuatif tiap tahunnya.

Selain itu, fenomena insufficient cash juga terlihat dari kasus beberapa perusahaan di Indonesia. Dalam beberapa artikel di internet, disebutkan beberapa perusahaan mengalami gagal bayar seperti PT Arpeni Ocean Line (APOL), PT Bumi Resources, PT Mobile-8 Telecom, Davomas International Finance Company, PT Barito Pasific Timber, dan yang lainnya. Gagal bayar merupakan ketidakmampuan perusahaan untuk melunasi pinjaman pokok beserta bunganya. Hal ini berarti perusahaan tidak memiliki kas yang cukup untuk melunasi kewajibannya. Dilihat secara sekilas, tentu hal ini berpengaruh pada kepercayaan para investor terhadap perusahaan yang bersangkutan.

Pengaruh dari excess dan insufficient cash ini berakibat pada kinerja dan juga dipengaruhi oleh kegiatan operasional. Hal ini 
akan diteliti dengan variabel dependen Return on Net Operating Asset (RNOA). Kemudian, terlepas dari apakah excess cash dan insufficient cash memiliki pengaruh positif atau negatif bagi kinerja perusahaan, penelitian ini juga akan melihat pengaruhnya terhadap reaksi investor atas kondisi ini. Reaksi pasar akan diukur dengan menggunakan Cumulative Abnormal Return (CAR) sebagai variabel dependen kedua.

\section{PENGEMBANGAN HIPOTESIS}

\subsection{Kajian Teoritis}

\subsubsection{Penentuan Target Saldo Kas}

Menurut Harmono (2011:197), karena sifatnya yang tidak produktif, kas harus dimiliki seminimal mungkin oleh perusahaan. Namun di sisi lain perusahaan membutuhkan banyak kas untuk kegiatan operasional sehingga perlu dicari posisi kas optimal.Ada berbagai model yang dapat digunakan untuk menentukan saldo kas yang dikehendaki, di antaranya adalah Baumol Model dan MillerOrr Model. Model yang digunakan dalam penelitian ini adalah model Miller-Orr. Model ini digunakan karena lebih sesuai dengan kondisi sebenarnya, yaitu saldo kas yang selalu berubah.

\subsubsection{Return on Net Operating Assets (RNOA)}

Kinerja perusahaan dapat dianalisis dengan berbagai cara. Analisis kinerja perusahaan membutuhkan analisis bersama secara integrative. Banyak analis memisahkan neraca dan laporan laba rugi menjadi komponen operasi dan non-operasi, dan menghitung return on net operating asset (RNOA) sebagai ringkasan ukuran kinerja. Pembagian laporan keuangan menjadi komponen operasi dan non-operasi didasarkan pandangan bahwa aktivitas operasi merupakan aktivitas yang paling bertahan lama dan relevan untuk penentuan harga saham.Aktivitas operasi merupakan aktivitas inti perusahaan.(Subramanyam, 2010:144-145)

Peneliti menggunakan return on net operating assets sebagai pengukur indikator kinerja keuangan karena RNOA lebih mencerminkan kontribusi terhadap profit dari segi operating net assets (kas termasuk di dalamnya).

\subsubsection{Cumulative Abnormal Return (CAR)}

Yustan (2007) dalam Agustina dan Kianto (2012) mengatakan bahwa laba merupakan salah satu elemen laporan keuangan yang memiliki kandungan informasi yang tinggi. Pengujian kandungan informasi dimaksudkan untuk melihat reaksi dari sesuatu pengumuman. Jika pengumuman mengandung informasi maka pasar diharapkan akan bereaksi pada waktu pengumuman tersebut diterima oleh pasar. Reaksi pasar ditunjukkan dengan adanya perubahan harga dari sekuritas yang bersangkutan. Reaksi ini dapat diukur dengan abnormal return. Jika menggunakan abnormal return, maka dapat dikatakan bahwa suatu pengumuman yang mengandung informasi akan memberikan abnormal return ke pasar. Sebaliknya yang tidak mengandung kandungan informasi tidak memberikan abnormal return pada pasar. (Ratih, 2002 dalam Agustina dan Kianto, 2012) 


\subsection{Kerangka Pemikiran}

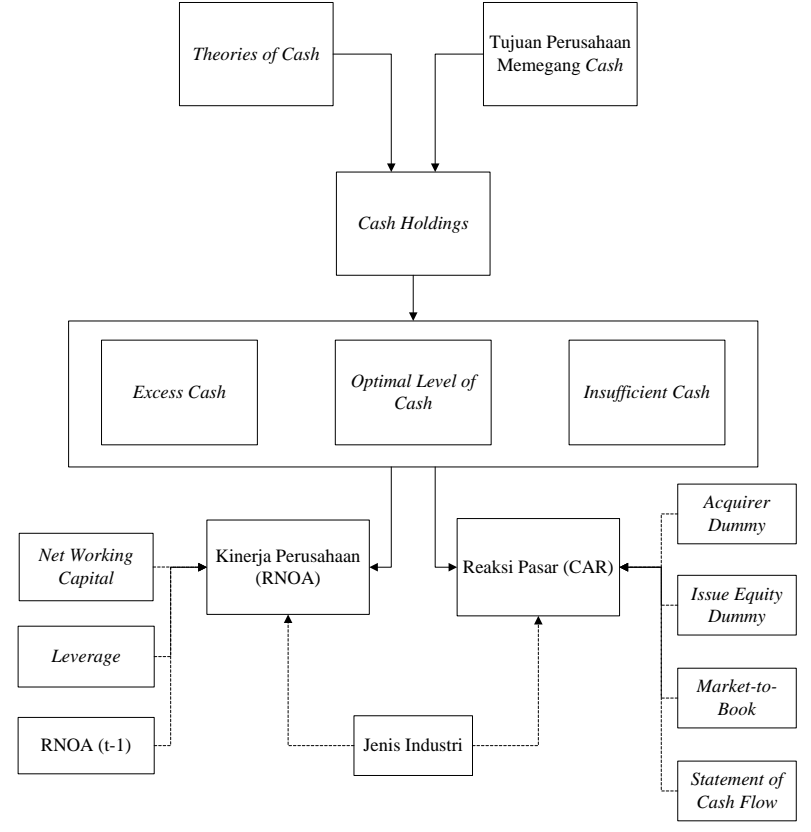

Gambar 1 Kerangka Pemikiran

Sumber: diolah peneliti

\subsection{Hipotesis}

\subsubsection{Pengaruh Cash Holdings terhadap Kinerja Perusahaan}

Cash management is a factor that has a positive impact on firm performance (Akbari, et al., 2014). Kinerja perusahaan dapat diukur oleh beberapa indikator, salah satunya oleh return on net operating assets (RNOA).Jensen (1986) and Richardson (2006) dalam Oler and Picconi (2014) menyatakan bahwa excess cash akan menyebabkan overinvestment in cash sehingga dampaknya adalah RNOA pun akan menurun karena kas yang tersedia bisa menghasilkan keuntungan tambahan jika digunakan untuk investasi pada proyek lain atau digunakan untuk aktivitas operasional perusahaan yang lainnya seperti membeli persediaan atau mesin, misalnya. Menurut motif transaksi yang digagas Keynes (1936), perusahaan yang memegang insufficient cash juga akan mengalami penurunan kinerja karena untuk menjalankan operasi perusahaan harus dikeluarkan tambahan biaya-biaya lagi yang muncul dari biaya karena external financing. Hipotesis yang dapat dibuat dari kondisi ini yakni:

$\mathrm{H}_{1}$ :Excess Cash berpengaruh negatif signifikan terhadap RNOA.

$\mathrm{H}_{2}$ :Insufficient Cash berpengaruh negatif signifikan terhadap RNOA.

\subsubsection{Pengaruh Cash Holdings terhadap Reaksi Pasar}

Asimetri informasi berarti para pemegang saham memiliki informasi yang kurang dibandingkan dengan manajemen perusahaan.Para pemegang saham atau investor menanamkan modal dengan tujuan mengharapkan return. Pada dasarnya, jika perusahaan memiliki banyak kas, investor akan berharap bahwa perusahaan akan menghasilkan return yang besar. Jumlah kas yang banyak juga menimbulkan anggapan bahwa perusahaan memiliki risiko yang kecil karena perusahaan akan mampu mengatasi kesulitan keuangannya.

Namun di sisi lain, kas yang banyak atau excess cash ini bisa juga menjadi sinyal negatif bagi investor. Jika investor memposisikan diri sebagai internal perusahaan, investor bisa melihat jika kas yang terlalu banyak akan berakibat lain. Selain itu, menurut Oler and Picconi (2014), saldo kas yang kurang (insufficient cash) juga menandakan manajemen perusahaan yang kurang bagus. Suatu hal yang wajar jika investor melihat jumlah kas pada laporan posisi keuangan perusahaan karena kas bisa dianggap sebagai pelindung di masa waktu yang kurang baik bagi perusahaan (investopedia). Keputusan investor ini bisa dilihat pada abnormal return. Mungkin saja bahwa abnormal return ini dipengaruhi oleh rasio keuangan lain, namun penelitian ini memfokuskan pada apakah jumlah kas yang menyimpang akan mempengaruhi reaksi pasar 
atau tidak. Hipotesis yang dapat dibuat dari kondisi ini yakni:

$\mathrm{H}_{3}$ :Excess Cash berpengaruh negatif terhadap CAR.

$\mathrm{H}_{4}$ :Insufficient Cash berpengaruh negatif terhadap CAR.

METODE PENELITIAN

\subsection{Metode Penelitian}

Penelitian ini merupakan penelitian kuantitatif. Penelitian kuantitatif dapat dilaksanakan dengan penelitian deskriptif (Margono, 1997 dalam Darmawan, 2013:37). Penelitian deskriptif merupakan penelitian yang dimaksudkan untuk mengumpulkan informasi mengenai status suatu gejala yang

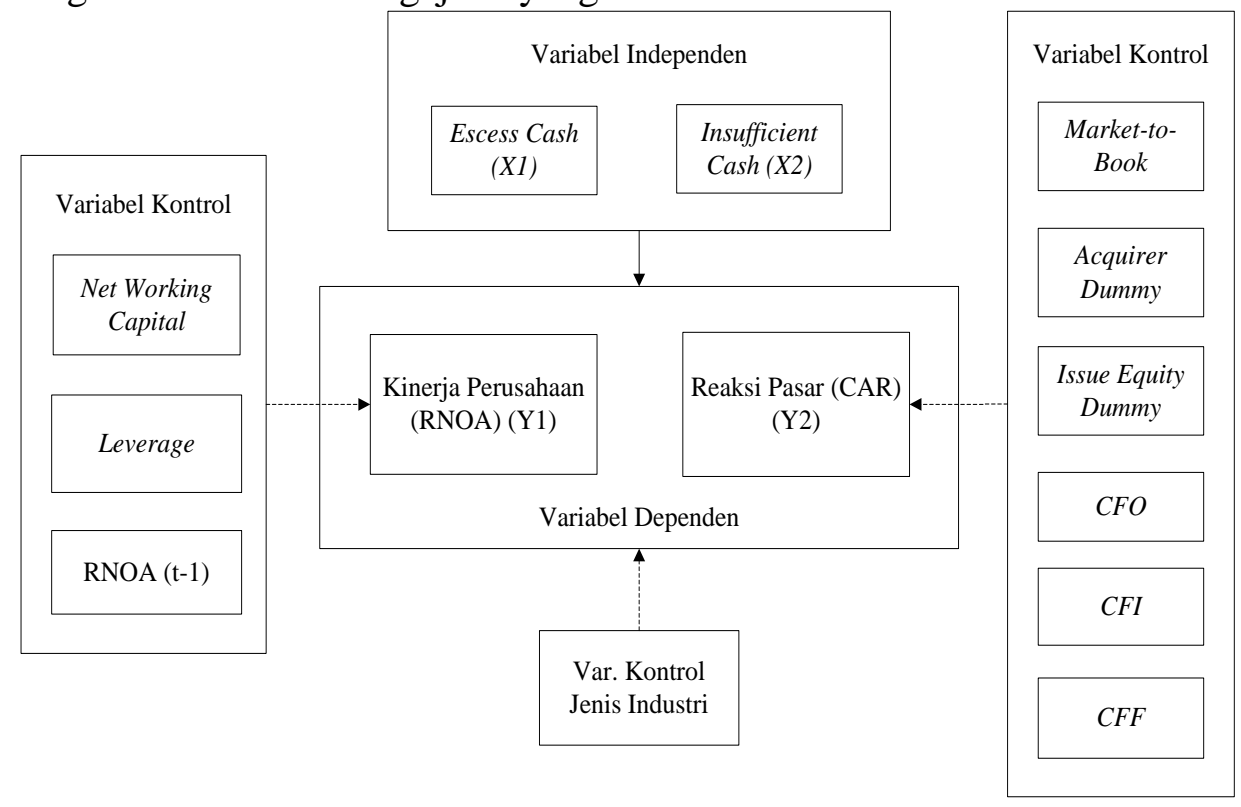

\section{Gambar 2 Model Penelitian}

ada, yaitu keadaan gejala menurut apa adanya pada saat penelitian dilakukan (Arikunto, 2005 dalam Darmawan, 2013:134).

\subsection{Model Penelitian}

sumber: diolah peneliti

Penelitian ini menggunakan analisis regresi berganda (multiple regression) untuk mengetahui besarnya pengaruh variabel independen terhadap variabel dependen. Penelitian ini dinyatakan dalam dua model penelitian sebagai berikut:

$$
\begin{aligned}
& \text { RNOA }_{i, t+1}=\alpha+\beta_{1}[\text { Excess Cash }]_{\mathrm{i}, \mathrm{t}}+\beta_{2}
\end{aligned}
$$

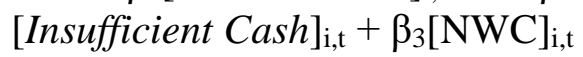

$$
\begin{aligned}
& +\beta_{4}[\text { Leverage }]_{\mathrm{i}, \mathrm{t}}+\beta_{5}[\text { Industry } \\
& \text { Dummy }]_{\mathrm{i}, \mathrm{t}}+\beta_{6}[\mathrm{RNOA}]_{\mathrm{i}, \mathrm{t}}+\epsilon \\
& \operatorname{CAR}_{\mathrm{i}, \mathrm{t}+1}=\alpha+\beta_{1}[\text { Excess Cash }]_{\mathrm{i}, \mathrm{t}}+\beta_{2}
\end{aligned}
$$

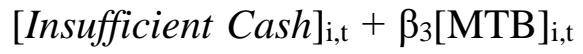

$$
\begin{aligned}
& +\beta_{4}[\text { Acquirer Dummy }]_{\mathrm{i}, \mathrm{t}}+
\end{aligned}
$$




$$
\begin{aligned}
& \beta_{5}[\text { Issue Equity Dummy }]_{\mathrm{i}, \mathrm{t}}+ \\
& \beta_{6}[\text { Industry Dummy }]_{\mathrm{i}, \mathrm{t}}+ \\
& \beta_{7}[\mathrm{CFO}]_{\mathrm{i}, \mathrm{t}}+\beta_{8}[\mathrm{CFI}]_{\mathrm{i}, \mathrm{t}}+\beta_{9} \\
& {[\mathrm{CFF}]_{\mathrm{i}, \mathrm{t}}+\epsilon}
\end{aligned}
$$

\subsection{Populasi dan Sampel}

Populasi dalam penelitian ini adalah seluruh perusahaan publik yang terdaftar di Bursa Efek Indonesia periode 20102013.Dalam penelitian ini digunakan metode probability sampling, dengan teknik proportionate stratified random sampling. Dengan menggunakan rumus Slovin, didapat jumlah sampel sebanyak 81 unit perusahaan.

\subsection{Uji Asumsi Klasik}

Uji asumsi klasik adalah persyaratan statistik yang harus dipenuhi pada analisis regresi linear berganda yang berbasis ordinary least square (OLS). Uji asumsi klasik ini meliputi:

1. Uji Normalitas

Uji normalitas adalah untuk melihat apakah nilai residual terdistribusi normal atau tidak.Model regresi yang baik adalah memiliki nilai residual yang terdistribusi normal.

2. Uji Multikolinearitas

Istilah kolinearitas ini menunjukkan adanya lebih dari satu hubungan linear yang sempurna.Uji multikolinearitas adalah untuk melihat ada atau tidaknya korelasi yang tinggi antara variabelvariabel bebas dalam suatu model regresi linear berganda.Jika ada korelasi yang tinggi di antara variabel-variabel bebasnya, maka hubungan antara variabel bebas terhadap variabel terikatnya menjadi terganggu.

3. Uji Heteroskedastisitas

Uji heteroskedastisitas adalah untuk melihat apakah terdapat ketidaksamaan varians dari residual satu pengamatan ke pengamatan yang lain. Model regresi yang memenuhi persyaratan adalah di mana terdapat kesamaan varians dari residual satu pengamatan ke pengamatan yang lain tetap atau disebut homoskedastisitas.

4. Uji Autokorelasi

Autokorelasi adalah korelasi antaranggota dari serangkaian observasi baik dalam waktu (data time series) atau ruang (data cross sectional) (Gujarati, 2004 dalam Khairani, 2012). Uji autokorelasi bertujuan untuk mengetahui ada tidaknya korelasi antara error pada periode tertentu dengan error periode sebelumnya. Pelanggaran asumsi ini biasanya timbul pada datatime series.

\subsection{Analisis Regresi Berganda}

Pengujian persamaan regresi ada dua, yaitu pengujian parsial (uji t) dan pengujian simultan (uji F).Pengujian parsial dilakukan untuk menentukan signifikan atau tidak signifikan masing-masing nilai koefisien regresi secara sendiri-sendiri terhadap variabel terikat.Pengujian simultan melibatkan semua variabel bebas terhadap variabel terikat dengan menguji ada tidaknya pengaruh yang signifikan secara simultan atau bersama-sama. Tingkat signifikansi yang digunakan dalam penelitian ini adalah sebesar $0,95(\alpha=0,05)$.

\subsection{Pengujian Data Panel}

Di dalam dataran aplikasi praktis terdapat banyak data yang merupakan kombinasi dari data bertipe cross-section dan data time series, yakni sejumlah variabel diobservasi atas sejumlah kategori dan dikumpulkan dalam suatu jangka waktu tertentu. Data demikian disebut sebagai data panel atau pooling, dan model yang digunakan untuk menganalisis data jenis ini disebut sebagai model data panel (Rosadi, 2012). Dengan menggabungkan antara observasi time-series dan cross-section, data panel memberi lebih banyak informasi, lebih banyak variasi, sedikit kolinearitas 
antarvariabel, dan lebih efisien (Gujarati, 2012:237).

\section{HASIL DAN PEMBAHASAN}

4.1 Hasil Penelitian

4.1.1 Model Penelitian Regresi Data Panel

Terdapat tiga model pendekatan regresi data panel, yakni pendekatan kuadrat terkecil (Pooled Least Square - PLS), pendekatan efek tetap (Fixed Effect Model - FEM), dan pendekatan model efek acak (Random Effect Model - REM). Model regresi data panel yang digunakan dalam penelitian ini adalah Pooled Least Square.

\subsubsection{Hasil Pengujian Asumsi Klasik 1.Uji Normalitas}

Untuk mengetahui normalitas data, distribusi dikatakan normal jika nilai asymptotic significance lebih besar dari $5 \%$.

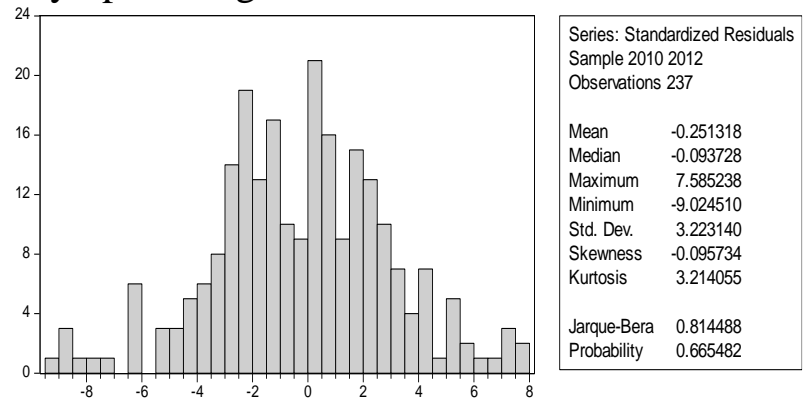

Gambar 3 Hasil Uji Normalitas Model Y1 sumber: output Eviews diolah peneliti
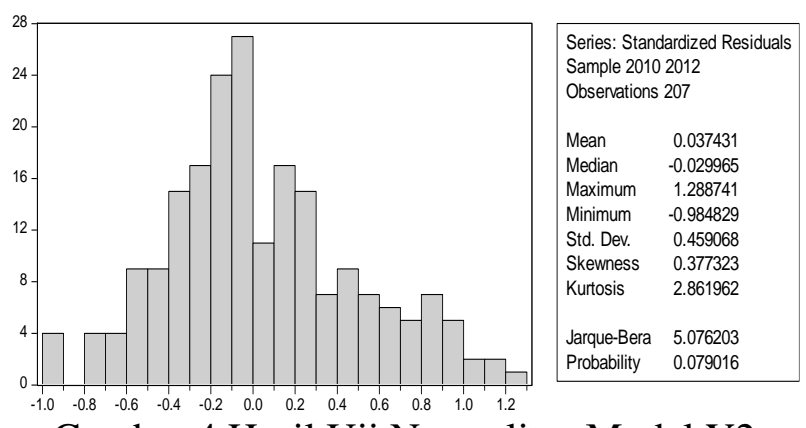

Gambar 4 Hasil Uji Normalitas Model Y2 sumber: output Eviews diolah peneliti

Berdasarkan hasil pengolahan tersebut, diperoleh bahwa distribusi data untuk kedua model Y1 dan Y2 berdistribusi normal sehingga dapat memenuhi uji asumsi klasik normalitas dan penelitian model regresi berganda dapat dilanjutkan.

\section{Uji Autokorelasi}

Uji autokorelasi dapat dilakukan dengan memperhatikan nilai Durbin Watson.Selain itu diperlukan juga nilai-nilai lain yang berkaitan dengan uji ini seperti dL (batas bawah) dan dU (batas atas) yang dapat diperoleh dari tabel Durbin Watson.Nilai DW yang diperoleh untuk model Y1 adalah 1.052178 dan untuk Y2 adalah 2.112052.

Dalam hasil uji autokorelasi model Y1, diperoleh nilai yang berkaitan dengan uji Durbin Watson sebagai berikut:

$$
\begin{array}{|l|l|l|l|l|}
\mathrm{DW}=1,0521 & \mathrm{dL}=1.643 & \mathrm{dU}=1.8967 & 4-\mathrm{dU}=2,1033 & 4-\mathrm{dL}=2,3569 \\
\hline
\end{array}
$$

Terlihat bahwa nilaiDW $<\mathrm{dL}$ yang berarti ada $\quad \mathrm{Y} 2$, diperoleh nilai yang berkaitan dengan uji autokorelasi positif. Sedangkan untuk model

\begin{tabular}{|l|l|l|l|l|}
\hline $\mathrm{dL}=1.6101$ & $\mathrm{dU}=1.9312$ & $4-\mathrm{dU}=2,0688$ & $\mathrm{DW}=2,1120$ & $4-\mathrm{dL}=2,3899$ \\
\hline
\end{tabular}

Terlihat bahwa 4-dU < DW < 4-dL yang berarti hasil autokorelasi tidak dapat disimpulkan.
Berdasarkan hasil pengujian tersebut, kedua model penelitian ternyata memiliki masalah autokorelasi. Masalah autokorelasi ini 
bisa disebabkan karena data yang mengandung time series dan juga adanya variabel dummy. Meskipun begitu, dengan menggunakan Eviews, masalah autokorelasi dapat diatasi dengan menggunakan model GLS (Generalized Least Square) dengan memberikan pembobotan (weighted) pada bagian cross section sehingga penelitian dapat dilanjutkan.

\section{Uji Multikolinearitas}

Multikolinearitas terjadi jika koefisien korelasi antarvariabel independen lebih besar dari 0,6 atau ada juga yang menyatakan lebih besar dari 0,5; 0,7; 0,8; atau 0,9. Berdasarkan hasil pengujian, untuk model Y1 maupun Y2 hubungan antarvariabel tidak ada yang kuat (tidak sampai mencapai 0,6) sehingga dapat disimpulkan bahwa tidak terjadi multikolinearitas dalam model penelitian ini.

\section{Uji Heteroskedastisitas}

Penggunaan data panel pada software Eviews tidak mengizinkan dilakukannya uji heteroskedastisitas. Namun, dengan software Eviews ini jika terjadi masalah heteroskedastisitas, ada cara tertentu dalam pengolahan data panel untuk mengatasinya yakni dengan cara melakukan pembobotan (weighted). Model regresi data panel dalam penelitian ini menggunakan Generalized Least Square dan menggunakan pembobotan sehingga diasumsikan data terbebas dari masalah heteroskedastisitas. Selain itu, karena penelitian ini menggunakan data panel, menurut Gujarati (2009:7) tidak semua asumsi dapat terpenuhi pada setiap tipe data. Faktanya, asumsi homoskedastisitas atau error variance yang sama, tidak selalu dapat dipertahankan pada data cross section. Adanya heteroskedastisitas bukan berarti suatu model regresi adalah lemah.

\subsubsection{Hasil Pengujian Statistik}

Berikut adalah output dari Eviews yang akan digunakan untuk pengujian hipotesis statistik untuk dua model variabel dependen Y1 dan Y2

Dari tabel tersebut maka diperoleh persamaan linear berganda model $\mathrm{Y}_{1}$ sebagai berikut:

$\mathrm{Y}_{1(\mathrm{t}+1)=} \quad 0.0015+\quad 0.5780 \mathrm{X}_{1(\mathrm{i}, \mathrm{t})}+$ $0.0890 \mathrm{X}_{2(\mathrm{i}, \mathrm{t})}+0.1593 \mathrm{X}_{3(\mathrm{i}, \mathrm{t})}-$ $0.1765 \mathrm{X}_{4(\mathrm{i}, \mathrm{t})}-0.0127 \mathrm{X}_{5(\mathrm{i}, \mathrm{t})}+$ $0.0812 \mathrm{D}_{1(\mathrm{i}, \mathrm{t})}+0.2911 \mathrm{D}_{2(\mathrm{i}, \mathrm{t})}+$ $0.2413 \mathrm{D}_{3(\mathrm{i}, \mathrm{t})}+0^{0.1819 \mathrm{D}_{4(\mathrm{i}, \mathrm{t})}+}+$ $0.2754 \mathrm{D}_{5(\mathrm{i}, \mathrm{t})}+0.1504 \mathrm{D}_{6(\mathrm{i}, \mathrm{t})}+$ $0.0702 \mathrm{D}_{7(\mathrm{i}, \mathrm{t})}$

Keterangan:

Y: $\quad$ Return on Net Operating Assets $_{(t+1)}$

X1: Excess Cash

X2: Insufficient Cash

X3: Net Working Capital

X4: Leverage

X5: Return on Net Operating Assets

D1: Industry Dummy, 1 jika mining, 0 jika bukan.

D2: Industry Dummy, 1 jika basic and chemical, 0 jika bukan.

D3: Industry Dummy, 1 jika miscellaneous, 0 jika bukan.

D4: Industry Dummy, 1 jika consumer goods, 0 jika bukan.

D5: Industry Dummy, 1 jika property and real estate, 0 jika bukan.

D6: Industry Dummy, 1 jika infrastructure and utilities, 0 jika bukan.

D7: Industry Dummy, 1 jika trade, service and investment, 0 jika bukan.

Sedangkan untuk model $\mathrm{Y}_{2}$ diperoleh hasil sebagai berikut.

Dari tabel tersebut maka diperoleh persamaan linear berganda model $\mathrm{Y}_{2}$ sebagai berikut:

$\mathrm{Y}_{2(\mathrm{t}+1)}=$ $\begin{array}{lccc}-0.0124 & 0.0329 \mathrm{X}_{1(\mathrm{i}, \mathrm{t})} & - \\ 0.0146 \mathrm{X}_{2(\mathrm{i}, \mathrm{t})} & - & 0.0011 \mathrm{X}_{3(\mathrm{i}, \mathrm{t})} & + \\ 0.2071 \mathrm{X}_{4(\mathrm{i}, \mathrm{t})} & + & 0.1081 \mathrm{X}_{5(\mathrm{i}, \mathrm{t})} & + \\ 0.1206 \mathrm{X}_{6(\mathrm{i}, \mathrm{t})} & - & 0.0084 \mathrm{X}_{7(\mathrm{i}, \mathrm{t})} & + \\ 0.0083 \mathrm{X}_{8\left(\mathrm{i}, \mathrm{t}^{-}\right.} & 0.0557 \mathrm{D}_{1(\mathrm{i}, \mathrm{t})} & +\end{array}$ 


$$
\begin{aligned}
& 0.0161 \mathrm{D}_{2(\mathrm{i}, \mathrm{t})}+0.1564 \mathrm{D}_{3(\mathrm{i}, \mathrm{t})}+ \\
& 0.0189 \mathrm{D}_{4(\mathrm{i}, \mathrm{t})}+0.0329 \mathrm{D}_{5(\mathrm{i}, \mathrm{t})}- \\
& 0.0040 \mathrm{D}_{6(\mathrm{i}, \mathrm{t})}+0.0038 \mathrm{D}_{7(\mathrm{i}, \mathrm{t})}
\end{aligned}
$$

Keterangan:

Y: Cumulative Abnormal Returns

X1: Excess Cash

$\mathrm{X} 2$ : Insufficient Cash

X3: Market-to-Book Ratio

X4: Cash from Operations

X5: Cash from Investing

X6: Cash from Financing

X7: Issue Equity Dummy

X8: Acquirer Dummy

D1: Industry Dummy, 1 jika mining, 0 jika bukan.

D2: Industry Dummy, 1 jika basic and chemical, 0 jika bukan.

D3: Industry Dummy, 1 jika miscellaneous, 0 jika bukan.

D4: Industry Dummy, 1 jika consumer goods, 0 jika bukan.

D5: Industry Dummy, 1 jika property and real estate, 0 jika bukan.

D6: Industry Dummy, 1 jika infrastructure and utilities, 0 jika bukan.

D7: Industry Dummy, 1 jika trade, service and investment, 0 jika bukan.

\section{Uji Signifikansi Simultan (Uji F)}

Uji $F$ bertujuan untuk menguji pengaruh semua variabel independen dalam penelitian secara simultan terhadap variabel dependen sehingga dapat diketahui bahwa model penelitian memang dapat diterapkan dalam penelitian (uji kecukupan model).

\section{Uji Signifikansi Parsial (Uji t)}

Uji $\mathrm{t}$ digunakan untuk mengetahui apakah variabel-variabel independen secara individual berpengaruh secara signifikan terhadap variabel dependen.Perlakuan yang sama juga dilakukan pada variabel kontrol.

\subsection{Pembahasan Hasil Penelitian}

Berdasarkan pengujian secara simultan, diperoleh hasil bahwa $\mathrm{H}_{0}$ ditolak yang berarti terdapat pengaruh signifikan secara simultan dari variabel independen Excess Cash dan Insufficient Cash terhadap variabel dependen RNOA ( $\left.\mathrm{Y}_{1}\right)$ maupun terhadap CAR $\left(\mathrm{Y}_{2}\right)$. Hal ini berarti bahwa kondisi kas yang menyimpang dari tingkat optimalnya, baik lebih besar (excess) atau lebih kecil (insufficient) akan secara bersama-sama mempengaruhi kinerja perusahaan yang diukur dengan RNOA dan reaksi pasar yang diukur dengan CAR. Namun secara parsial, beberapa variabel independen dan variabel kontrol berpengaruh signifikan dan ada pula yang tidak signifikan.

\subsubsection{Pembahasan Model RNOA ( $\left.\mathrm{Y}_{1}\right)$ 1. Variabel Independen Excess Cash Variabel independen Excess} Cashmemiliki pengaruh positif terhadap RNOA.Hal ini berlawanan dengan hipotesis awal penelitian yang menyatakan bahwa Excess Cash berpengaruh negatif terhadap RNOA.Selain itu, pengaruh positif ini juga bernilai signifikan.Walaupun berlawanan dengan hipotesis awal $\left(\mathrm{H}_{\mathrm{a}}\right.$ ditolak), hasil penelitian ini sesuai dengan penelitian terdahulu yang dilakukan Kim, Mauer, and Sherman (1998); Opler, Pinkowitz, Stuzl, and Williamson (1999); dan Mikkelson and Partch (2003), dengan hasil bahwa perusahaanperusahaan yang memiliki saldo kas yang berlebih (Excess Cash) memiliki kinerja yang lebih baik. Kas yang berlebih bisa menjadi sinyal positif bagi perusahaan bahwa target perusahaan tercapai dan memicu kinerja yang lebih baik lagi.

Kim, Mauer, and Sherman (1998) dan Opler, Pinkowitz, Stulz, and Williamson (1999) meneliti tentang cash holdings dan menemukan bahwa perusahaan dengan kas yang besar secara umum sejalan dengan motif yang menambah value perusahaan.Menurut 
Mikkelson and Partch, perusahaan yang memegang kas yang banyak berarti perusahaan tersebut dapat mengantisipasi kesempatan investasi masa depan.Selain itu, dengan memiliki banyak kas perusahaan dapat menurangi external financing dan dapat mengurangi biaya yang berkaitan dengan hal tersebut.Perusahaan yang memegang banyak kas ini sesuai dengan motif perusahaan memegang kas yakni precautionary motive (motif berjaga-jaga).

\section{Variabel Independen Insufficient Cash}

Variabel independen Insufficient Cash memiliki pengaruh positif terhadap variabel dependen RNOA yang berarti $\mathrm{H}_{\mathrm{a}}$ ditolak. Hal ini berlawanan dengan hipotesis awal penelitian tetapi karena hasilnya tidak signifikan maka peneliti menyimpulkan penyimpangan ini terjadi karena sebab lain yaitu sampel yang kurang sesuai dikarenakan dari sekian banyak sampel dan unit observasi yang diteliti, kasus insufficient cash tidak banyak terjadi.

\section{Variabel Kontrol Model $\mathbf{Y}_{1}$}

Variabel kontrol Net Working Capital berpengaruh positif dan signifikan terhadap RNOA. Hal ini menjelaskan bahwa likuiditas yang baik akan membuat kinerja perusahaan lebih baik. Variabel kontrol Leverage berpengaruh negatif dan signifikan terhadap RNOA.Hal ini menjelaskan bahwa perusahaan yang memiliki banyak kewajiban (debt) cenderung mengalami penurunan kinerja.Variabel kontrol RNOA berpengaruh negatif terhadap RNOA tahun berikutnya.Namun pengaruh negatif ini bersifat tidak signifikan sehingga pengaruh RNOA terhadap RNOA setahun setelahnya bisa diabaikan. Hal ini menjelaskan bahwa kinerja perusahaan setiap tahunnya tercapai murni atas kinerja periode tersebut dan tidak dipengaruhi kinerja sebelumnya. Variabel kontrol Industry Dummy dari semua jenis industri yang ada dalam model penelitian seluruhnya berpengaruh positif terhadap RNOA secara parsial. Namun pengaruh positif ini tidak bersifat signifikan yang berarti pada model penelitian ini variabel jenis perusahaan tidak memiliki dampak yang berarti terhadap RNOA.

\subsubsection{Pembahasan Model CAR ( $\left.\mathrm{Y}_{2}\right)$ 1. Variabel Independen Excess Cash}

Variabel independen Excess Cash negatif terhadap variabel dependen CAR.Hal ini sesuai dengan hipotesis awal penelitian yang menyatakan bahwa pasar beraksi negatif terhadap jumlah kas yang berlebih dari nilai optimalnya.Namun pengaruh negatif ini tidak bersifat signifikan yang berarti secara keseluruhan investor tidak terlalu bereaksi pada kondisi excess cash.

\section{Variabel Independen Insufficient Cash}

Variabel Insufficient Cash berpengaruh negatif terhadap CAR yang juga sesuai dengan hipotesis awal penelitian.Pengaruh negatif ini juga bersifat signifikan yang berarti investor memang memberikan respon negatif terhadap perusahaan yang memiliki kas yang kurang.Dibandingkan dengan hasil analisis variabel Excess Cash yang tidak signifikan, hal ini memperlihatkan bahwa di Indonesia, para investor tidak begitu merespon kelebihan kas yang dimiliki perusahaan tetapi lebih merespon terhadap kekurangan kas perusahaan.Hal ini wajar terjadi karena kas yang sedikit lebih memicu kekhawatiran investor terhadap kelangsungan hidup perusahaan sedangkan kas yang berlebih belum banyak diperhatikan oleh investor dan selain itu bisa saja investor lebih memilih perusahaan yang memiliki kas yang banyak sesuai dengan motif precautionary.

\section{Variabel Kontrol Model $\mathrm{Y}_{2}$}

Variabel kontrol Market-to-Book memiliki pengaruh negatif terhadap CAR.Hal ini berlawanan dengan prediksi awal yang menyatakan bahwa pasar merespon positif 
rasio MTB.Meskipun begitu, pengaruh negatif ini tidak signifikan sehingga penyimpangan ini diasumsikan tidak bermasalah karena secara keseluruhan investor tidak mempertimbangkan MTB.

Informasi laporan keuangan yang diproksikan dengan variabel Cash from Operations, Cash from Investing, dan Cash from Financing secara parsial memiliki pengaruh positif dan signifikan terhadap CAR. Hal ini membuktikan bahwa informasi yang disajikan laporan arus kas sangat dibutuhkan oleh investor.Namun terdapat satu penyimpangan prediksi tanda dari ketiga variabel ini. $\mathrm{CFO}$ dan $\mathrm{CFF}$ memang diprediksikan berpengaruh positif sedangkan variabel CFI diprediksikan berpengaruh negatif karena penggunaan kas untuk investasi lebih menggambarkan kondisi yang baik (perusahaan banyak berinvestasi). Dari hasil uji parsial ini CFI berpengaruh positif karena CFI yang positif (perusahaan banyak menjual investasi) bisa juga menunjukkan cara perusahaan untuk memperoleh keuntungan dari selisih harga investasinya.

Variabel kontrol Issue Equity Dummy berpengaruh negatif, yang berarti pasar merespon negatif terhadap penerbitan saham yang dilakukan perusahaan, sedangkan Acquirer Dummy berpengaruh positif, yang berarti pasar merespon positif jika perusahaan melakukan akuisisi. Namun kedua variabel ini tidak berpengaruh signifikan terhadap CAR sehingga bisa disimpulkan kedua kondisi tersebut tidak begitu diperhatikan investor.

Berkenaan dengan jenis perusahaan, investor memberikan respon negatif jika perusahaan merupakan mining industry dan respon positif untuk perusahaan miscellaneous industry.Pergerakan indeks saham mining memangsedang mengalami penurunan di periode ini. Sedangkan sektor miscellaneous yang meliputi perusahaan sejenis Astra dan sebagainya termasuk yang diminati investor karena perkembangannya yang baik. Kedua variabel industry dummy ini bersifat signifikan pengaruhnya terhadap CAR. Sisa variabel Industry Dummy lainnya berpengaruh positif untuk basic and chemical, consumer goods, property and real estate, dan trade, service and investment. Pengaruh negatif dihasilkan dari industry dummy infrastructure and utilities.Namun dibandingkan mining dan miscellaneous industry, variabel-variabel ini tidak berpengaruh signifikan secara parsial terhadap CAR.

\section{KESIMPULAN, KETERBATASAN DAN SARAN}

5.1 Kesimpulan

Penelitian ini bertujuan untuk menemukan apakah variabel independen yang terdiri dari Excess Cash dan Insufficient Cash memiliki pengaruh terhadap kinerja perusahaan yang diukur dengan Return On Net Operating Assets (RNOA) dan terhadap reaksi pasar yang diukur dengan Cumulative Abnormal Return (CAR) dengan menggunakan variabel kontrol Net Working Capital, Leverage, RNOA, Market-to-Book, Cash Flow Information, Issue Equity Dummy, Acquirer Dummy, dan Industry Dummy.Penelitian dilakukan pada perusahaanperusahaan sektor non-keuangan yang terdaftar di Bursa Efek Indonesia (BEI) selama periode 2010-2013.Model penelitian diestimasikan dengan menggunakan Pooled Least Square (PLS) - Generalized Least Square. Berdasarkan hasil analisis dan pembahasan pada bab sebelumnya, berikut beberapa hal yang dapat disimpulkan:

1. Variabel independen Excess Cash berpengaruh positif dan signifikan terhadap variabel dependen RNOA karena kondisi Excess Cash sesuai dengan precautionary motive dan dapat membuat perusahaan siap dengan kesempatan investasi di masa yang akan datang yang dapat meningkatkan kinerja. Selain itu dengan kas yang banyak, 
perusahaan dapat menghindari biaya external financing.

2. Variabel independen Insufficient Cash berpengaruh positif terhadap variabel dependen RNOA tetapi tidak signifikan dikarenakan sampel yang digunakan tidak banyak menampilkan hasil insufficient cash.

3. Variabel independen Excess Cash berpengaruh negatif terhadap variabel dependen CAR tetapi tidak signifikan karena investor tidak menganggap kelebihan kas sebagai informasi yang relevan.

4. Variabel independen Insufficient Cash berpengaruh negatif dan signifikan terhadap variabel dependen CAR karena kondisi kas yang kurang akan memberi sinyal yang buruk terhadap investor Investor tentu akan merasa khawatir jika mereka berinvestasi di perusahaan yang tidak memiliki cukup kas karena khawatir tidak akan mendapatkan return yang sesuai.

Pada penelitian ini digunakan dua variabel independen yang sama untuk dua variabel dependen yang berbeda sehingga digunakanlah dua model regresi berganda untuk masing-masing variabel dependen (RNOA dan CAR). Hal yang dapat disimpulkan dari kedua model regresi ini adalah bahwa variabel independen Excess Cash dan Insufficient Cash lebih kuat pengaruhnya terhadap reaksi pasar yang diukur dengan CAR dibandingkan terhadap kinerja perusahaan yang diukur dengan RNOA.

\subsection{Keterbatasan dan Saran}

Berdasarkan hasil penelitian yang telah dikemukakan maka dapat diberikan beberapa saran sebagai berikut:

1. Bagi peneliti selanjutnya, akan lebih baik jika dalam penelitiannya lebih mempertimbangkan variabel kontrol lain yang lebih berpengaruh terhadap hubungan variabel independen dan variabel dependen seperti yang digunakan Oler and Picconi(2014) yang mencakup kualitas akrual, sales growth, firm age, dan capital expenditure. Selain itu, bisa juga mencoba model lain untuk mendapatkan jumlah optimal kas yang sesuai, seperti model Opler et al. (1999) yang menggunakan estimasi regresi untuk memperoleh nilai saldo kas optimal. Peneliti selanjutnya dapat pula melakukan metode sampling lain yang akan menghasilkan model regresi yang lebih signifikan.

2. Bagi investor dan perusahaan, untuk mempedulikan komposisi kas yang dimiliki perusahaan karena dalam penelitian ini, variabel independen Excess Cash dan Insufficient Cash berpengaruh signifikan baik terhadap RNOA maupun CAR secara simultan. Namun secara parsial, perusahaan dapat tetap memegang kas dalam jumlah besar karena akan berdampak positif terhadap kinerja. Selain itu perusahaan harus berhati-hati pada kondisi kekurangan kas karena investor sangat merespon negatif kondisi ini.

\section{DAFTAR PUSTAKA}

\section{Buku:}

Atmaja, L. S. 2008. Teori dan Praktik Manajemen Keuangan. Jakarta: Penerbit Andi.

Darmawan, D. 2013. Metode Penelitian Kuantitatif. Bandung: PT Remaja Rosdakarya.

Efferin, S.,S. H. Darmadji, dan Y. Tan. 2008. Metode Penelitian Akuntansi; Mengungkap Fenomena dengan Pendekatan Kuantitatif dan Kualitatif. Yogyakarta: Graha Ilmu.

Fahmi, I. 2013. Pengantar Manajemen Keuangan; Teori dan Soal Jawab. Bandung: Penerbit Alfabeta. 
Firdaus, M. 2011. Ekonometrika, Suatu Pendekatan Aplikatif. Edisi Kedua. Jakarta: Bumi Aksara.

Gujarati, D. N. 2007a.Dasar-Dasar Ekonometrika.Edisi Ketiga. Jilid 1. Diterjemahkan oleh: Julius A. Mulyadi. Jakarta: Penerbit Erlangga.

Gujarati, D. N. andD. C. Porter . 2009.Basic Econometrics.Fifth Edition. Singapore: The McGraw-Hill.

Gujarati, D. N. dan D. C. Porter. 2012. DasarDasar Ekonometrika. Buku 2, Edisi 5. Diterjemahkan oleh: Raden Carlos Mangunsong. Jakarta: Salemba Empat.

Harmono.2011. Manajemen Keuangan; Berbasis Balanced Scorecard, Pendekatan Teori, Kasus, dan Riset Bisnis. Jakarta: Bumi Aksara.

Ikatan Akuntan Indonesia.2012. Standar Akuntansi Keuangan No. 2: Laporan Arus Kas.Jakarta: Salemba Empat.

Kuncoro, M. 2009. Metode Riset untuk Bisnis \& Ekonomi; Bagaimana Meneliti dan Menulis Tesis?Edisi 3.Jakarta: Penerbit Erlangga.

Nazir, M. 2005. Metode Penelitian. Bogor: Penerbit Ghalia Indonesia.

Rosadi, D. 2012. Ekonometrika \& Analisis Runtun Waktu Terapan dengan EViews. Yogyakarta: Penerbit Andi

Subramanyam, K. R. dan J. J. Wild. 2013. Analisis Laporan Keuangan.Edisi 10.Buku 2. Diterjemahkan oleh: Dewi Yanti. Jakarta: Penerbit Salemba Empat.

Suliyanto. 2009. Metode Riset Bisnis. Yogyakarta: Penerbit Andi.

Sunyoto, D. 2013. Metodologi Penelitian Akuntansi. Bandung: PT Refika Aditama.

\section{Jurnal:}

Agustina, L. dan F. Kianto.2012. Pengaruh Informasi Laba Akuntansi terhadap Abnormal Return pada Perusahaan yang Tergabung dalam Indeks LQ45.
Jurnal Akuntansi Vol. 4 No. 2, hal. 135152.

Akbari, M. A., S. Rahmani, R.Ahmadi, and H. Shababi. 2014. Deviation from Optimal Level of Cash Holdings and Cumulative Abormal Returns. Universal Journal of Accounting and Finance.Vol. 2 No. 4, pp 88-96.

Bates, T. W., K. M. Kahle, and R. M. Stulz. 2009. Why Do U.S. Firms Hold So Much More Cash than They Used To? The Journal of Finance.Vol. LXIV, No. 5, pp 1985-2021.

Christina, Y. T. dan E. Ekawati. 2014. Excess Cash Holdings dan Kepemilikan Institusional pada Perusahaan Manufaktur yang Terdaftar di BEI. Jurnal Manajemen Strategi Bisnis dan Kewirausahaan Vol. 8 No. 1, hal 1-10.

Mikkelson, W. H. and M. M. Partch. 2003. Do Persistent Large Cash Reserves Hinder Performance? Journal of Financial and Quantitative Analysis. Vol. 38 No. 2, pp. 275-294.

Nelvianti. 2013. Pengaruh Informasi Laporan Arus Kas, Laba, dan Ukuran Perusahaan terhadap Abnormal Return Saham pada Perusahaan Manufaktur yang Terdaftar di Bursa Efek Indonesia. Artikel skripsi persayaratan wisuda, Universitas Negeri Padang.

Oler, D. K. and M. P. Picconi. 2014. Implications of Insufficient and Excess Cash for Future Performance. Contemporary Accounting Research. Vol. 31 No. 1, pp. 253-283.

Saddour, K. 2006. The Determinants and The Valaue of Cash Holdings: Evidence from French Firms. Entre de Recherches sur la Gestion.University Paris Dauphine.

Sadeghi, Z., M. A. Jahanshahi, and A. K. Darranji. 2014. Measuring Excess Cash Balance and Studying Its Relationship with Stock Return in Companies 
Accepted in Tehran Stock Exchange. International Journal of Academic Research in Accounting, Finance, and Management Sciences. Vol. 4 No. 1, pp 340-351.

\section{Skripsi dan penelitian lain:}

Khairani, I. 2012. Analisis Pengaruh Board Governance dan Cash Holdings terhadap Nilai Perusahaan (Studi Empiris pada Perusahaan-Perusahaan yang Terdaftar di Bursa Efek Indonesia Periode 2005-2010).Skripsi Sarjana.Universitas Indonesia.Depok.

Mambraku, M. E. 2014. Pengaruh Cash Holding dan Struktur Kepemilikan Manajerial terhadap Income Smoothing (Studi Empiris pada Perusahaan Manufaktur yang Terdaftar di Bursa Efek Indonesia Periode 20102012).Skripsi Sarjana. Universitas Dipenogoro, Semarang.

Niati, F. 2012. Pengaruh Corporate Governance, Kepemilikan Manajerial, dan Cash Holding dalam Upaya Meningkatkan Kesejahteraan Pemegang Saham.Skripsi Sarjana. Universitas Indonesia: Depok.

Jinkar, R. T. 2013. Analisa Faktor- Faktor Penentu Kebijakan Cash Holding Perusahaan Manufaktur di Indonesia.Artikel Fakultas Ekonomi Universitas Indonesia.

\section{Internet:}

Indonesia Stock Exchange, Bursa Efek Indonesia. (http://www.idx.co.id/)

Indonesian Capital Market Electronic Library. (http://www.icamel.id/)

Iqbal, M. 2015. Regresi Data Panel.Tersedia online http://dosen.perbanasinstitute.ac.id (diakses 1 April 2015).

Konsultan Statistik. 2009. Uji Asumsi Klasik.Tersedia online: http://www.konsultanstatistik.com/200 9/03/uji-asumsi-klasik.html (diakses 9 Januari 2015).

Yahoo Finance. (http://finance.yahoo.com) 
Journal Accounting and Finance

Edisi Vol. 3 No. 2 September 2019

Universitas Telkom 